\title{
Spanish translation, cultural adaptation and validation of the new version of Demoralization Scale (DS-II): multicenter study in advanced cancer patients
}

\section{INTRODUCTION}

Demoralization refers to a situation of existential distress in patients with advanced illness. Typically it is characterized by coping difficulties, feelings of loss of sense and purpose in life and despair, among other things. Demoralization is a treatable condition and DS-II is an evaluation tool for this syndrome, which has recently been reformulated.

\section{METHODOLOGY}

- Translation and cultural adaptation was carried out using the procedure of the European Organization for Research and Treatment of Cancer. This version was pilot tested to verify its validity.

- A validation study was then undertaken, including advanced cancer patients attended by five palliative care teams in Spain Argentina, Chile and El Salvador.

- Health professionals collected the data on: DS-II (es), Hospital Anxiety and Depression Scale (HADS), Edmonton Symptom Assessment System-revised (ESAS-r) and Karnosky Performance Status.

- The analysis conducted measured statistically these aspects:

- Reliability according to internal consistency.

- Construct validity and concurrent validity with HADS \& ESAS-r.

- Discriminant validity using The Karnofsky Performance Status scale.

- Feasibility, with response ratio and time required.

- Cut off points, sensitivity and specificity.

\section{RESULTS}

- 150 patients completed the validation study and the Spanish version of DS-II was obtained.

- The Spanish version of the scale is now available (Belar et al., 2019).

- Cronbach's Alpha for DS-II was 0.88, for the sense and purpose subscale it was 0.83 and for distress and coping ability, 0.79 .

- A confirmatory analysis using structural equation models with their corresponding latent constructs showed that all the items correlated positively on their subscales and on the overall scale.

- DS-II (es) correlated significative with HADS (rho=0.73, p<0.001).

- Cut-off points at scores 10 and 20 out of 32 were stablished.

- The scale showed high sensitivity $(81.97 \%)$ and specificity (80.90\%).

- DS-II (es) is feasible for patients with advanced cancer.

- The prevalence of demoralization was $33 \%$ in our sample.

\section{OBJECTIVES}

- To obtain a Spanish version of DS-II and check its psychometric properties in advanced cancer patients in Spain and some LatinAmerican countries.

- To gain an insight into the prevalence of demoralization in spanish talking advanced cancer patients.

\begin{tabular}{|c|c|c|c|c|}
\hline \multicolumn{5}{|c|}{$\begin{array}{l}\text { DS-lll (es) } \\
\text { Por favor indique cuantas veces se ha sentido de esta manera durante las dos útimas semanas } \\
\text { rodeando el número correspondiente en cada una de las afirmaciones que siguen }\end{array}$} \\
\hline Afirmaciones & Nunca & $\begin{array}{c}\begin{array}{c}\text { Algunas } \\
\text { veces }\end{array} \\
\end{array}$ & $\begin{array}{l}\text { Todo el } \\
\text { tiempo } \\
\end{array}$ & subescatia \\
\hline 1. Lo que puedo ofrecer a otros tiene poco valor & 0 & 1 & 2 & 5 \\
\hline 2 Mi vida parece no tener sentido & 0 & 1 & 2 & 3 \\
\hline 3. He perdido mi papel o rol en la vida & 0 & 1 & 2 & 3 \\
\hline 4. Siento que no tengo control sobre mis emociones & o & 1 & 2 & A \\
\hline 5. Nadie me puede avudar & 0 & 1 & 2 & 5 \\
\hline 6. Siento que no puedo ayudarme a mi mismo & 0 & 1 & 2 & 5 \\
\hline 7. Me siento sin esperanza & 0 & 1 & 2 & 5 \\
\hline 8. Me siento irritable & 0 & 1 & 2 & A \\
\hline 9. No afronto bien la vida & 0 & 1 & 2 & A \\
\hline 10. Lamento muchas cosas de mi vida & 0 & 1 & 2 & A \\
\hline 11. Tiendo a sentirme dolido fácilmente & $\circ$ & 1 & 2 & A \\
\hline 12. Me siento angustiado por to que me está pasando & $\circ$ & 1 & 2 & A \\
\hline 13. No soy una persona valiosa & $\circ$ & 1 & 2 & 5 \\
\hline 14. Preferiria no estar vivo & 0 & 1 & 2 & 5 \\
\hline 15. Me siento bastante aislado o solo & 0 & 1 & 2 & A \\
\hline 16. Me siento atrapado por lo que me está ocurriendo & 0 & 1 & 2 & A \\
\hline \multicolumn{3}{|c|}{ Puntuaciones } & Obtenidos & Totales \\
\hline \multicolumn{3}{|c|}{ A: subescatia de capacidad de afrontamiento } & & 16 \\
\hline \multicolumn{3}{|c|}{ S: subescala de sentido y propósito de la vida } & & 16 \\
\hline \multicolumn{3}{|c|}{ Desmoralizacion (c10 susente, $10-19$ moderada, 220 severa) } & & 32 \\
\hline \multicolumn{5}{|c|}{ DS-II (es) scale (Belar et al., 2019) } \\
\hline
\end{tabular}

\section{CONCLUSIONS}

The Spanish version of the new demoralization scale (DS-II) has been shown to be valid, reliable and feasible with adequate psychometric properties when tested on advanced cancer patients.

\section{REFERENCES}

Dewolf L, Koller M, Velikova G. EORTC quality of life group translation procedure. 3rd ed. Brussels: European Organization for Research and Treatment of Cancer; 2009. 9-10 p.

- Robinson S, Kissane DW, Brooker J, Michael N, Fischer J, Franco M, et al. Refinement and revalidation of the demoralization scale: The DS-II-internal validity. Cancer. 2016:122(14):2251-9.

- Robinson S, Kissane DW, Brooker J, Hempton C, Michael N, Fischer J, et al. Refinement and revalidation of the demoralization scale: The DS-II-external validity. Cancer. 2016 Jul;122(14):2260-7.

- Belar A, Arantzamendi M, Rodríguez-Núñez A, Santesteban Y, Martinez M, López-Saca M, Consigli S, López-Fidalgo J, Centeno C. Multicenter Study of the Psychometric Properties of the New Demoralization Scale (DS-II) in Spanish-Speaking Advanced Cancer Patients. J Pain Symptom Manage. 2019 Mar:57(3):627-634.
Founding: This work has been funded by the project PI/1801703, integrated in the Plan Estatal de $1+D+1$ 2013-2016 and co-funded by the ISCIII-Subdirección General de Evaluación y Fomento de la investigación y el Fondo Europeo de Desarrollo Regional (FEDER)

Author of correspondence: Alazne Belar Beitia Universidad de Navarra, ICS, Programa de investigación Atlantes, Pamplona. abelar@alumni.unaves Instituto de Investigación Sanitaria de Navarra (IdisNA) 